\title{
TACTILE PROPERTIES OF FABRICS
}

\section{Silvana Zhezhova '", Sonja Jordeva', Sashka Golomeova Longurova', Vangja Dimitrijeva - Kuzmanoska' ${ }^{1}$ Tanja Dimova'}

\author{
'University "Goce Delchev", Shtip, Faculty of Technology \\ Miro Baraga bb., Probištip, Republic of North Macedonia \\ *e-mail: silvana.zezova@ugd.edu.mk
}

\author{
Stručni rad \\ UDC: 677.022 .47 \\ doi:10.5937/tekstind1902004Z
}

\begin{abstract}
The tactile properties of fabrics are the most important features that affect the quality of the finished products and the decision of the customer when purchasing one. Conventional methods for evaluating the comfort and the impact of the fabric on human senses are based on subjective examination of tactile properties. Among the various properties of fabrics, surface features are those that might contribute most to the individual perception when touching the fabric. The texture of the fabric can be evaluated by sensation of touch (tactile evaluation), sensation of sight (visual evaluation), and on the basis of the two senses combined together (tactile-visual evaluation). One of the goals of this paper is to identify the most appropriate attributes for description of fabrics, and also to indicate some of the contemporary research on prediction of tactile properties of fabrics.
\end{abstract}

Key words: subjective evaluation, tactile properties, texture of fabrics.

\section{TAKTILNA SVOJSTVA TKANINA}

\begin{abstract}
Apstrakt: Taktilna svojstva tkanina su najvažnije karakteristike koje utiču na kvalitet gotovih proizvoda i odluku kupca prilikom kupovine. Konvencionalne metode za ocenu udobnosti (komfora) i uticaja tkanine na ljudska čula zasnivaju se na subjektivnom ispitivanju taktilnih svojstava. Među različitim svojstvima tkanina, površinske karakteristike su one koje najviše doprinose o individualnoj percepciji kada neko dodiruje tkaninu. Tekstura tkanine se može proceniti osećajem dodira (taktilna procena), osećajem vida (vizuelna procena) i na osnovu oba čula kombinovana zajedno (taktilno-vizuelna procena). Jedan od ciljeva ovog rada je da se identifikuju najprikladniji atributi za opis tkanina, kao i napraviti pregled nekih savremenih istraživanja u kontekstu predviđanju taktilnih svojstava tkanina.
\end{abstract}

Ključne reči: subjektivna procena, taktilna svojstva, tekstura tkanina.

\section{INTRODUCTION}

The textile industry produces products for different use, which should meet the requirements of different categories of consumers in terms of price, durability, fashion, comfort and quality. The technological achievements and sociological changes in the last 50-60 years are strongly reflected on the textile industry. The development of synthetic fibers, new systems for spinning, weaving and knitting, the development in finishing have caused radical changes in the processes of production, wear and maintenance of textile products.
However, in the 1980s, Kawabata noted that despite the advances in technology, the quality of the textile materials produced by modern technology was not improved, in terms of fabric handle, rather had become even worse. This estimate was obtained as a result of customer's feedback. However, this assessment could not be quantified precisely in the absence of an accepted methodology for the subjective evaluation of fabrics and textile materials in general [1].

Subjective feeling we get from the fabric is a complex result of many psychological and physiological responses of the human body to physical impulses. Because of this, the textile research also includes 
questions about how the properties of fabrics affect the feeling that they cause to the subject when it touches them, when it sees them, or sees and touches them.

The tactile properties of fabrics are one of the most important features that influence the quality of final products and the consumer's decisions when buying one. Textile materials that are used in close contact with the human body create an interaction between characteristics of the material and the human senses. Although the properties of the textile materials, such as strength and durability are very important, consumers also require product to be comfortable and to give a pleasant feeling when is used in close contact with the human body.

Conventional methods for assessing comfort and impact on human senses are based on the subjective examination of tactile properties. Studies have shown that there is a strong relationship between the properties of the fabrics and the perceived touch $[2,3]$. The properties of the fabric depend on many factors such as:

- Fiber characteristics (type of fiber (natural, synthetic), structure, length, fineness etc.),

- Yarn characteristics (staple, filament, textured yarn, linear density, twist of yarn, etc.),

- Fabric structure and geometry (method of production - knitted, woven, non-woven), yarn density, weight, thickness, etc.

- Type of dyeing and finishing process (calendaring, softening, brushing etc.)

Among the various properties of fabric surface characteristics are those that may most contribute to the individual perception of the touch of a fabric.

\section{EVALUATION OF THE SENSORY PROPERTIES OF FABRICS}

Evaluations of textile materials (woven or knitted fabrics) made externally by people (subjects) are called subjective, while evaluations carried out by using measuring instruments (objects) are called objective measurements [4].

However, a distinction should be made between the psychophysical measurement and the hedonistic choice. The first one refers to person who quantifies his (her) perception of the properties of the fabric (such as, softness, rigidity) and the second one refers to his (her) preferences for one textile material over another. Most often giving an advantage of one textile material over another is subconsciously or instinctively, but it may also contain elements of personal experience or knowledge. According to Pierce [5], 1930, the pioneer in objective measurements "Evaluation depends on time and place, seasons, personal persuasion and, therefore, whenever is possible, it should be replaced by a numerical result of a physical test." The perceptual experience resulting from fabric manipulation is called subjective hand evaluation.

A subjective hand evaluation can be defined in the following ways:

- Personal assessment of the material we feel between fingers and thumb;

- A set of all feelings that occur when a textile material is handled by touching, twisting, or smoothing;

- What a person sensually estimates from the mechanical properties of textile material.

Although some of the definitions refer only to the sense of touch, others also include the perceptions by other senses.

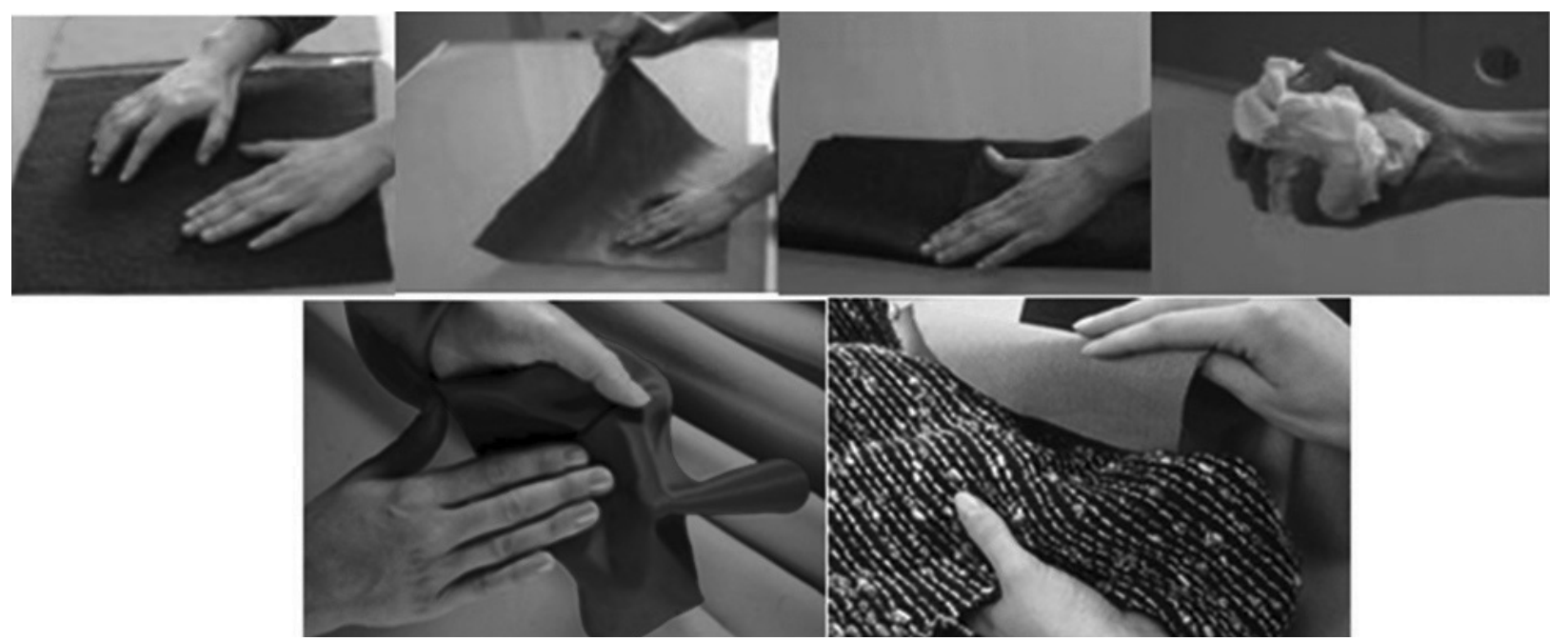

Figure 1: Fabric evaluation through touch 
Most often the subjective evaluation is based on:

- Sense of touch (tactile evaluation (Figure 1),

- Sense of sight (visual evaluation),

- Sense of touch and sight (tactile-visual evaluation).

Any kind of subjective evaluation is not sufficiently reliable, and therefore attempts are always made to make a correlation between the subjective evaluation and the instrumental measurements of the fabric properties. Laughlin, 1991 [6], acclaimed that the tactile-visual evaluation is at a higher level than the tactile evaluation and that it will give better result and distinction between the fabrics than the tactile one. Today it is widely accepted that the handle perception of the textile material derives from the brain interpretation to tactile stimuli, which in turn are correlated to the surface and mechanical properties of the material. The visual stimulation is included in the assessment, when is required by the test mode.

\section{ELEMENTS OF SUBJECTIVE EVALUATION}

The key elements of the subjective evaluation can be defined as:

1. Judges (assessors);

2. Criteria (selection of descriptors for textile material attributes);

3. Assessment conditions (whether the visual stimulation is included, temperature and relative humidity);

4. Assessment technique (prescribed manner of performing the test);

5. Method of classifying the assessments;

6. Analysis of the results (in the analysis of the results, the descriptors and correlation between them have special significance).

\subsection{Judges-assessors}

In practice, a commercial decision for buying textile material is made by individuals or small trained groups for making a decision about the suitability of the material for a particular purpose. Such decisions are not based only on subjective evaluation, but also depend on the construction of the fabric, its finishing, price and other characteristics relevant for specific end-use. For these reasons, when experts are used as "judges" (assessors) in subjective evaluation, they can not override previous experience and knowledge.
Their decision is never only result of visual and tactile perception, even when they are trying to neglecting their experience and knowledge. From this it arises, that it is not a surprise that very rarely there is agreement in the judgments of expert and naive judges.

Everyone can do a subjective evaluation, but that does not mean that it immediately qualifies those people as experts for buying or selling textile material. Stearn, Darsy and Postle, 1988, compared the skills of experts and non-experts judges (usually consumers of fabrics). They selected a group of judges composed of 18 Australians, 14 Indians, 8 Japanese and 13 New Zealand experts plus 9 Australian consumers. These judges made a total evaluation of 214 fabrics designed for man winter suits. The analysis of the results took into account the results of 39 judges. It was concluded that consumer judges showed greater variability in the assessment from expert judges. However, in the assessments made by the expert judges, there were great differences especially in 23 of them $[7,8]$.

In further investigations of softness, conducted by Niwa and Ishida, 1978, the differences in assessments between expert and non-expert judges are increasingly reduced [9].

\subsection{Criteria for evaluation}

In order to make handle (subjective) evaluation of the fabric, it is necessary to have a set of criteria. If the fabrics are judged by the words best or worst, we do not have a clear idea of what it actually is. These words are not explicit enough and do not give a precise assessment of the fabric. They do not actually contain the element of quantification of a particular property. Therefore we will focus on "generation of words or phrases" that describe the attributes of fabrics in order to be used to quantify sensory responses by subjects to tactile, visual and tactile-visual stimuli.

Several authors worked on this "dictionary", Brand, Vaughn, Kim, Howorth and Oliver. As a result, a "dictionary" was created with more than 100 descriptors selected from the literature. However, judges do not use such large number of descriptors, they use relatively few attributes of fabric as criteria of judgment.

First Howorth and Oliver in 1958, and then many other researchers like Kawabata and Niwa, 1989 [10, $11]$, distinguished the most frequently used descriptors. Howorth and Oliver worked with a group of 25 laboratory assistants (who did not have any experience of subjective evaluation of fabrics), which was supposed to rank 27 samples of woolen fabrics for suits. The samples were given in pairs and the assess- 


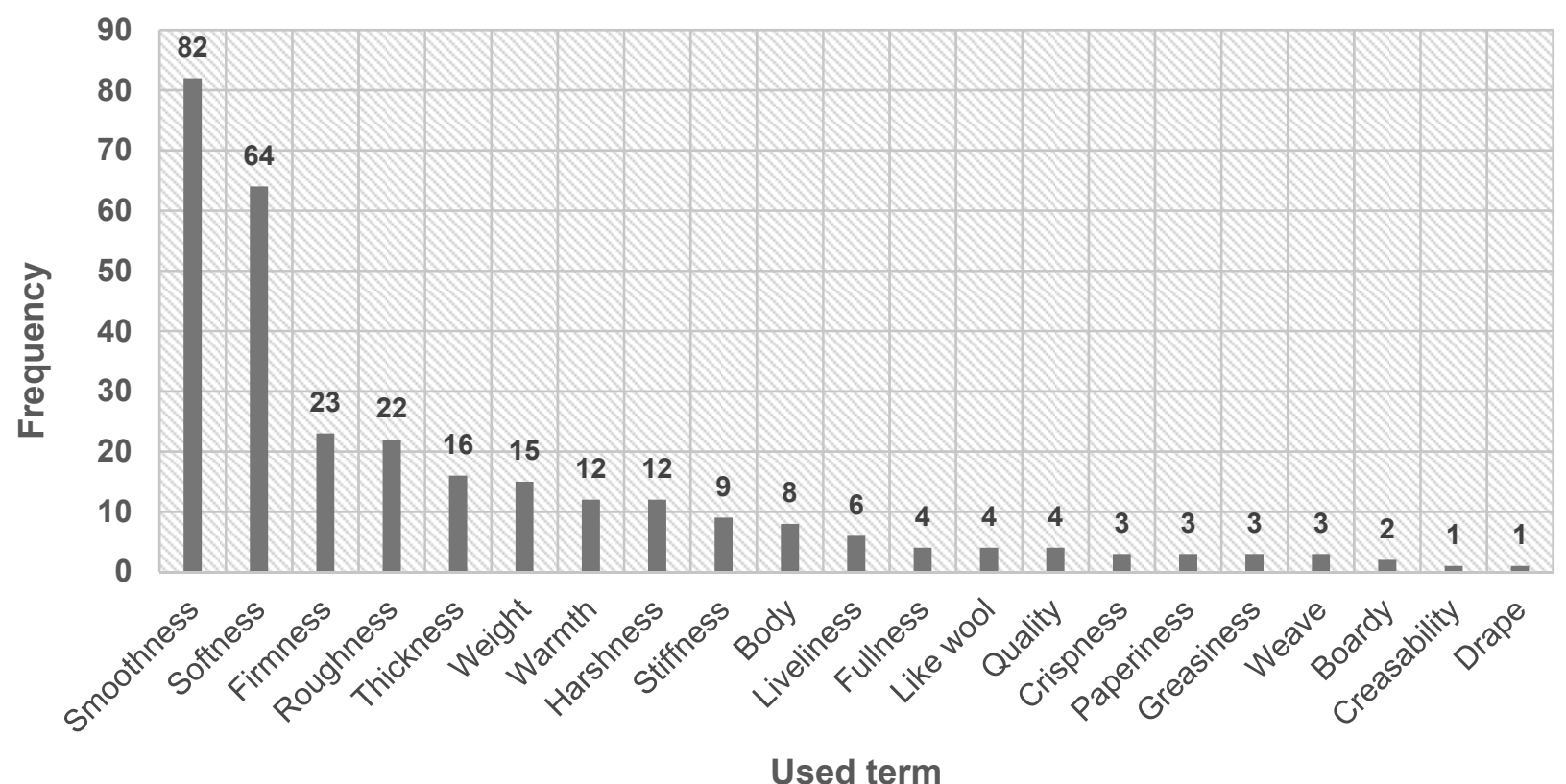

Figure 2: Descriptive terms for evaluation of fabrics

ment was performed without seeing the samples and by using a comparison technique. Each judge was individually asked to state the reason for refusing or accepting a particular sample from a pair. All the descriptive terms used by the judges were recorded and entered, as well as the frequency of their use. These data are given in figure 2. Figure 2 shows that $86 \%$ of all decisions were made on the basis of the 9 most commonly used descriptors. Further investigations of the same fabrics continued with the elimination of those descriptors which gave insignificant results.

With the principle of elimination Howorth and Oliver, 1958 came to a list of the 7 most important descriptors [11]:

\section{Smoothness}

\section{Softness}

\section{Roughness}

\section{Thickness}

\section{Weight \\ 6. Warmth}

\section{Stiffness.}

It should be noted that there are no descriptors in this group that refer to the outer appearance because the samples were evaluated without being seen. David et al., 1985 [12] discussed with each judge the choice of used term and offered him a word with the opposite meaning. In this way list of bipolar descriptors, were created. By eliminating the descriptors that did not give significant results, 7 typical bipolar pairs of descriptors are distinguished (Table 1).

Table 1: Typical bipolar couples of descriptors

\begin{tabular}{|c|c|c|c|c|c|c|c|c|c|}
\hline & Scale & 1 & 2 & 3 & 4 & 5 & 6 & 7 & \\
\hline 1 & Coarse & & & & & & & & Fine \\
\hline 2 & Stiff & & & & & & & & Pliable \\
\hline 3 & Rough & & & & & & & & Smooth \\
\hline 4 & Harsh & & & & & & & & Soft \\
\hline 5 & Cool & & & & & & & & Warm \\
\hline 6 & Hard & & & & & & & & Soft (in squeezing) \\
\hline 7 & Rigidity & & & & & & & & Quiet \\
\hline
\end{tabular}

1- as far below average; 2 - well below average; 3 - below average; 4 -average; 5 - above average; 6 - well above average; 7 - as far above average 
This list has similarity to the list of Howorth and Oliver, but the absence of weight and thickness is surprising. The presence of descriptors such as rigidity - quiet, is interesting especially when the judges do not see the material. The selected tactile characteristics of the fabrics can be related to some physical-mechanical characteristics such as the ability to drape, the resistance to smoothing, the thickness of the fabric, the resistance to pressure, the elastic and frictional properties [13].

The use of bipolar descriptors is favored by other authors that are working in this field. According to Byrne et.al, 1998 [14] the technique of bipolar descriptors has its origins in the so-called "semanticdifferential" technique.

\subsection{Conditions used for subjective evaluation}

The conditions used for subjective evaluation are critically important, because they influence the assessment. Under conditions, we usually mean the temperature and relative humidity of the air (they actually affect the mechanical and surface properties of fabrics). Also, the conditions of the hand - whether the skin is hard or softer, smooth or coarse, sweaty or dry etc., influence of ability to differentiate small tactile differences. When the moisture level on the hand is higher the skin is more sensitive to the sense of touch. This in turn requires controlling the climatic conditions and protocol under which the testing is carried out. It should be emphasized here that the conditions used for the evaluation also influence the assessment.

Usually instrumental measurements of the mechanical properties of fabrics are made at a tempera- ture of $20^{\circ} \mathrm{C}$ and a relative humidity of 65 , so the same conditions are used for the subjective evaluation. This is important, especially when we need to make a correlation between instrumental measurement and subjective evaluation. It is often forgotten to state the conditions under which the subjective evaluation was carried out, or or whether it is requested from the judges wash their hands, dry them and wait for acclimatization of a certain period of time before the test begins. When the subjective evaluation is the basis for scientific research, the same standards used for objective measurements must be applied (Figure 3).

\subsection{Techniques for subjective evaluation}

The instincts of judges vary, so they often evaluate the attributes of the fabric very differently. For this reason, the discussion about the way how the fabric is touching, i.e. the prescribed technique for subjective evaluation, arises. When there is a well-established methodology, all judges will be trained to perform the evaluation of the fabric in the same way. The fingers are the most important organs for determining the quality of textile material, because they contain more than 250 sensors per $\mathrm{cm}^{2}$ [15]. For subjective evaluation of fabric fingers are slid on the surface of the fabric or the fabric is compressed between the thumb and sign finger. Different hand methods are used to evaluate the different properties of materials. Generally 4 handle methods are used for subjective hand evaluation of textile materials: a-Touch stroke, b-Rotating cupped, c-Multiple finger, d-Two handed rotation) [16]. These handle techniques are given in Figure 4. Thus, the first and third method are usual-
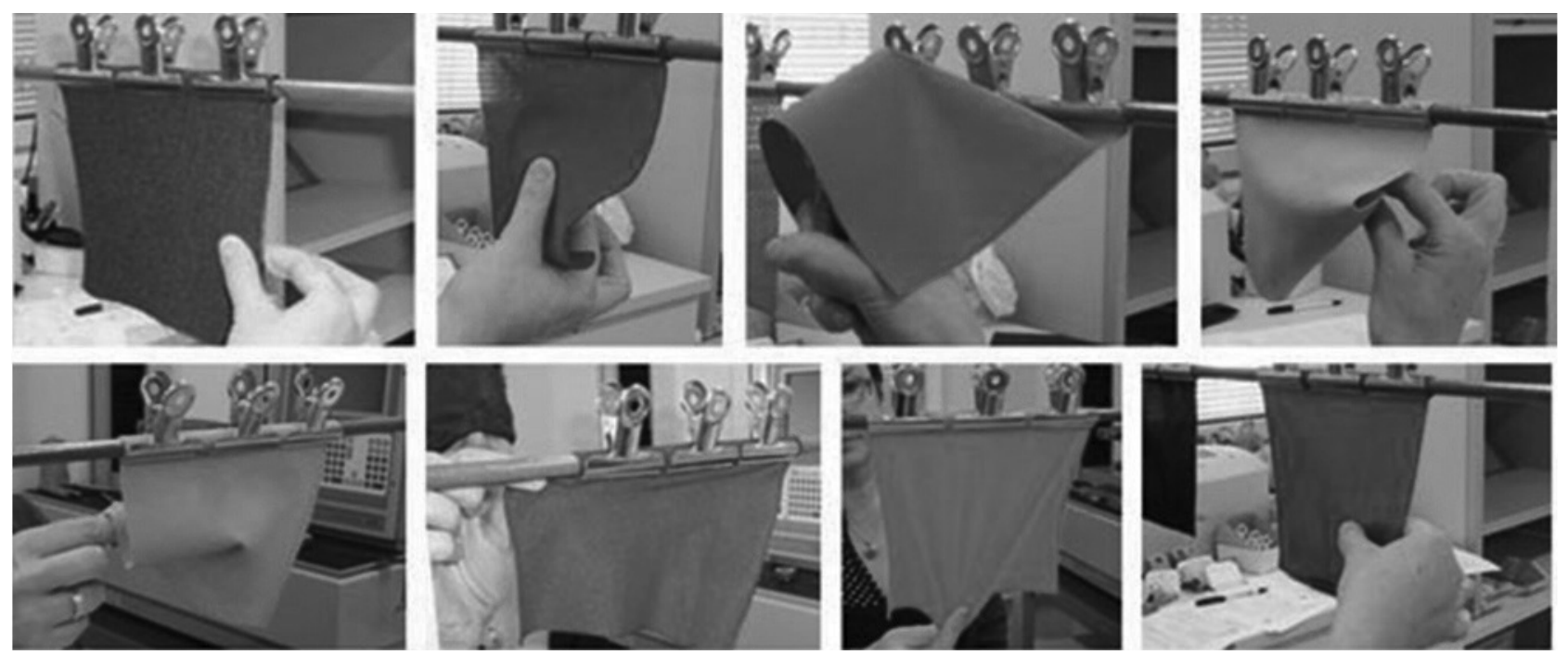

Figure 3: Subjective evaluation of fabric 


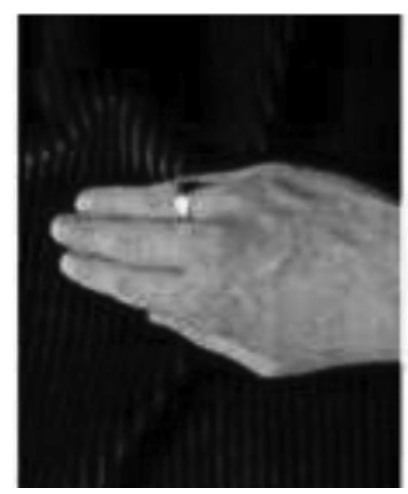

a)

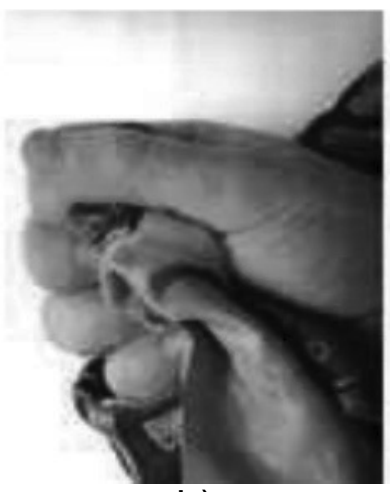

b)

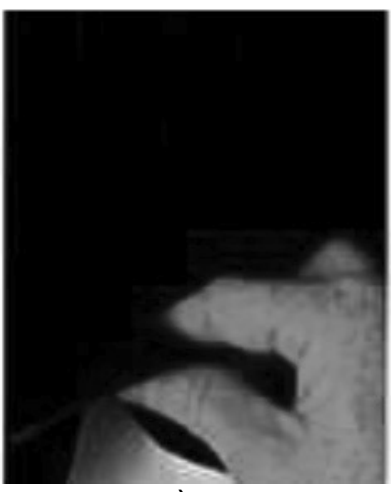

c)

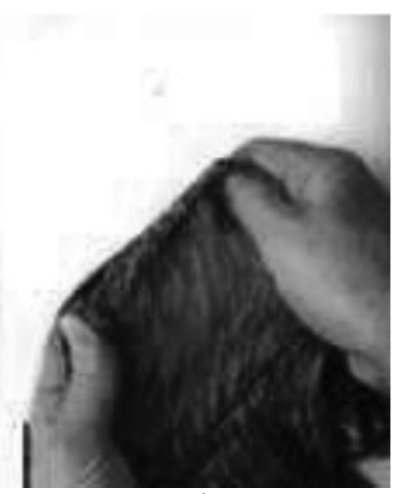

d)

Figure 4: Handle methods: a) Touch stroke, b) Rotating cupped, c) Multiple finger, d)Two handed rotation [16]

ly used to estimate the texture and structure of fabric, temperature. The second hand method (rotating cupped) is usually used for evaluating weight, stiffness, creasing, comfort, temperature and overall texture. And the two handed rotation method is used for determining the sheerness and stretch of fabric.

\subsection{Analysis and presentation of results}

The methods used to analyse and present the results of the subjective evaluation depend on the scope of the study's objectives. In order to have confidence in the obtain results from the subjective evaluation it is necessary to do:

- a statistical analysis that establishes a difference between the variation of the property between the samples and the variation of the property in the sample itself;

- the margin of significant discrimination between the samples;

- the level of agreement among the judges

\section{CONCLUSION}

Tensile properties are one of the most significant properties managing the performance of textile materials during usage. Predictions of consumer perception based on the material properties is very important for manufactures of textile materials and products. Conventional methods for evaluating the quality of textile materials have relied on subjective inspection of the tactile properties of the material using the human hand. Subjective hand evaluation is combination of different receptors responsible for feeling of surface quality, temperature, stiffness, stretching, deformation and etc. and from the sum of their complex responses humans can perceive and discriminate between the textiles. This subjective evaluation requires years of experience and can obviously be influenced by the personal preferences (age, gender, educations, etc.) of the judges. Because of the importance of the tactile property, much effort has been invested to replace the subjective assessment of fabrics by experts with an objective machine- based system which will give consistent and reproducible results.

\section{REFERENCES}

[1] Kawabata, S. (1982). The Development of the Objective Measurement of Fabric Handle, Objective Specification of Fabric Quality, Mechanical Properties and Performance, Osaka, Japan.

[2] Ajayi, J.O. (1992), Effect of fabric structure on frictional properties. Textile Research Journal 62 (2), 87-93.

[3] Aliouche, D., Viallier, P. (2000). Mechanical and tactile compression of fabrics: influence on handle. Textile Research Journal 70 (11),939-944.

[4] Bishop D.P. (1996). Fabrics: Sensory and mechanical properties. Textile Progress, Vol. 26, Issue 3, p.162 ,

[5] Peirce, F.T. (1930). The handle of cloth as a measurable quantity, Journal of the Textile Institute Transactions, 21, (9), 377-416.

[6] Laughlin, J. (1991). Int. J. Clothing Sci. Technol., 3(1), 28.

[7] Stearn, A. E., D'arey, R. L., Postle, R., and Mahar, T. J. (1988). A statistical analysis of subjective and objective methods of evaluating fabric handle part 
2: Relationships between subjective and objective measurements. Journal of Textile Machinery Society of Japan, 34(2), 39-46.

[8] Postle, R. (1990). Fabric objective measurement technology, present status and future potential, International Journal of Clothing Science and Technology, 2(3), 7-17.

[9] Niwa, M. and Ishida, M. (1978). An analysis of "softness" of fabrics. Journal of the textile machinery society of Japan 31, 403-410.

[10] Kawabata, S. and Niwa, M. (1989). Fabric performance in clothing and clothing manufacture, Journal of the Textile Institute, 80 (1), 19-50.

[11] Howorth, W. S. and Oliver, P. H. (1958). The application of multiple factor analysis to the assessment of fabric handle, Journal of the Textile Institute, 49(10), 540-553.

[12] David, H.G, Steam, A.E. and Denby, E.F. (1985). The Subjective Assessment of Handle, Proceedings of Third Japan- Australia Symposium on Objective
Measurement. Applications to Product Design and Process Control, Kyoto,Textile Machinery Society of Japan, Osaka, Japan, 527-536.

[13] Zafirova, K. (2001). Dizajn na tekstilnite povrsini, Univerzitet "Sv. Kiril i Metodij”, Skopje.

[14] Byme, M.S., Gardner, A.P.W. and Frtiz, A.M. (1993). 7 Te.xt. Inst., 84, 275.

[15] Bensaid, S., Osselin, J-F., Schacher, L. \& Adolphe, D. (2006). The Effect of Pattern Construction on the Tactile Feeling Evaluated Through Sensory Analysis, The Journal of The Textile Institute, (97), 2, 137-145.

[16] Moody, W., Morgan, R., Dillon, P., Baber, C., \& Wing, A. (2001). Factors Underlying Fabric Perception. In: 1st Eurohaptics Conference Proceedings. Birmingham

Rad primljen: 30.05.2019.

Rad prihvaćen: 20.06.2019. 